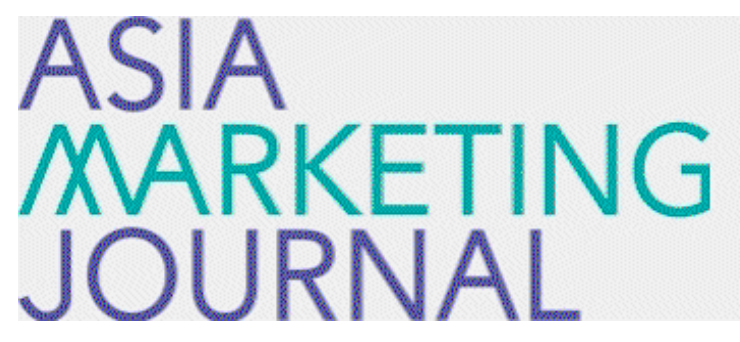

ASIA MARKETING JOURNAL

Volume 19 | Issue 4

Article 6

$1-31-2018$

\title{
ASIA MARKETING JOURNAL Vol.19 No.4 목차
}

Follow this and additional works at: https://amj.kma.re.kr/journal

Part of the Marketing Commons

\section{Recommended Citation}

(2018) "ASIA MARKETING JOURNAL Vol.19 No.4 목차," Asia Marketing Journal: Vol. 19 : Iss. 4 , Article 6. Available at: https://doi.org/10.53728/2765-6500.1461

This Article is brought to you for free and open access by Asia Marketing Journal. It has been accepted for inclusion in Asia Marketing Journal by an authorized editor of Asia Marketing Journal. 


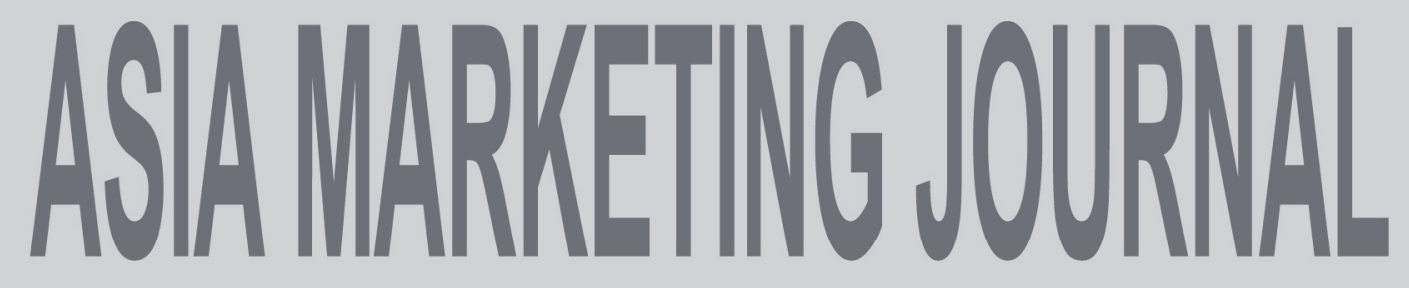

\section{Vol. 19 No. 01 April 2017}

\section{$<$ Research Paper $>$}

The Impact of Consumer Evaluation on the Cause-Related Marketing

Chia-Lin Lee — 1

How Network Structure Impacts Firm Performance:

The Moderating Effect of Network Openness and Interfirm Governance

Peer Effects in Service Usage

To Conform or Not to Conform: Mixed Conformity Model 